Cahiers $d u$ MONDE RUSSE

\section{Cahiers du monde russe}

Russie - Empire russe - Union soviétique et États indépendants

42/2-4 | 2001

La police politique en Union soviétique, 1918-1953

\title{
Dual subordination? The political police and the party in the Urals region, 1918-1953.
}

\author{
James HARRIS
}

\section{OpenEdition}

\section{Journals}

Édition électronique

URL : https://journals.openedition.org/monderusse/8462

DOI : $10.4000 /$ monderusse. 8462

ISSN : $1777-5388$

Éditeur

Éditions de l'EHESS

Édition imprimée

Date de publication : 1 avril 2001

Pagination : 423-446

ISBN : 2-7132-1398-3

ISSN : $1252-6576$

Référence électronique

James HARRIS, «Dual subordination? The political police and the party in the Urals region, 1918-1953. », Cahiers du monde russe [En ligne], 42/2-4 | 2001, mis en ligne le 01 janvier 2007, consulté le 04 septembre 2022. URL : http://journals.openedition.org/monderusse/8462 ; DOI : https://doi.org/10.4000/monderusse.8462 
chercher : repérer : avancer

Cet article est disponible en ligne à l'adresse :

http://www.cairn.info/article.php?ID REVUE=CMR\&ID NUMPUBLIE=CMR 422\&ID ARTICLE=CMR 4220423

Dual subordination ? The political police and the party in the Urals region, 1918-1953

par James HARRIS

Editions de l'EHESS | Cahiers du monde russe

2001/2-3-4 - Vol 42

ISSN 1252-6576 | ISBN 2713213983 | pages 423 à 446

Pour citer cet article :

- HARRISJ., Dual subordination ? The political police and the party in the Urals region, 1918-1953, Cahiers du monde russe $2001 / 2-3-4$, Vol 42, p. 423-446.

Distribution électronique Cairn pour les Editions de l'EHESS.

(C) Editions de l'EHESS. Tous droits réservés pour tous pays.

La reproduction ou représentation de cet article, notamment par photocopie, n'est autorisée que dans les limites des conditions générales d'utilisation du site ou, le cas échéant, des conditions générales de la licence souscrite par votre établissement. Toute autre reproduction ou représentation, en tout ou partie, sous quelque forme et de quelque manière que ce soit, est interdite sauf accord préalable et écrit de l'éditeur, en dehors des cas prévus par la législation en vigueur en France. Il est précisé que son stockage dans une base de données est également interdit. 


\section{DUAL SUBORDINATION? THE POLITICAL POLICE AND THE PARTY IN THE URALS REGION 1918-1953}

Who did the Soviet political police answer to? Few existing studies of the Soviet "organs" (Cheka, OGPU, NKVD, MGB, MVD) analyse in depth the significance of their structures and lines of subordination. This is particularly striking given that a substantial majority ${ }^{1}$ of political police officials worked in the regions, subordinated at the same time both to regional party committee, and to the central "organs" in Moscow. Many scholars have nevertheless worked from the assumption that the apparatus of the political police as a whole was a tool of the highest party leadership and of Stalin in particular. ${ }^{2}$ However, even some Cold War-era studies hesitated to accept such assumptions without qualification. In Smolensk under Soviet rule, Merle Fainsod pointed out that in the 1930s the regional party recruited most officials of the political police, and that the regional party secretary "directly handled problems involving [them]." To what extent did the local agents of the political police answer to the local party and not the centre? Fainsod admitted that the documentary record could not provide an answer. ${ }^{3}$

1. George Leggett, The Cheka: Lenin's political police (Oxford, 1986): 100. Leggett suggests that in 1918 there were 9,000 cadres in the regions versus 1,300 in Moscow headquarters (not including border guards and troops). By 1944, there were 367,350 in the regions versus 7,450 in the centre. A further 400,462 worked in the Gulag system. B. A. Starkov, "Gosudarstvo v gosudarstve. Evoliutsiia OGPU-NKVD-MVD-KGB” (unpublished).

2. Carl Friedrich and Zbigniew Brzezinski, Totalitarian dictatorship and autocracy (Cambridge, Mass., 1965): ch. 2; Ronald Hingley, The Russian secret police (London, 1970): 134; Boris Levytsky, The uses of terror: the Soviet secret service, 1917-1970 (London, 1971): 65; John J. Dziak, Chekisty: A history of the KGB (Lexington, Mass., 1988) : 52. Others go so far as to argue that the political police was determining the direction of state policy. See for example Robert Conquest, Inside Stalin's secret police (Stanford, 1985): ix.

3. Merle Fainsod, Smolensk under Soviet rule (Cambridge, Mass., 1958): 67, 158. 
Almost thirty years later, in his study of the Cheka, George Leggett examined the controversies over the relationship of the regional political police organs and regional Soviet and party authorities in the early years of the Soviet regime. Hampered, as was Fainsod, by the poverty of the sources, he nevertheless observed that the centre shrank from resolving the controversial matter of who was subordinate to whom. ${ }^{4}$

The following examination of the archives in Moscow and Sverdlovsk oblast' shows that the relationship of the regional political police and regional party organisations could be both collaborative and antagonistic. In the decade and a half of Soviet power, it was more collaborative than perhaps the central leadership might have preferred. In the Urals region, the fact that the party apparatus appointed, paid and provided perks of employment to political police officials generally made them highly sympathetic to the local party. ${ }^{5}$ While the local Cheka/ OGPU/NKVD officials responded loyally to directives of the central leadership, they also served and protected their local masters. At first, dual subordination involved few contradictions, but by the early 1930s the local and central agendas had diverged substantially. When this was discovered, in the course of the Great Terror, new measures were introduced to safeguard the independence of the NKVD. After 1937, antagonism, rather than collaboration, characterised the relationship of the regional political police and party organisations in the Urals region.

The close relationship between the political police and the oblast' leadership deepened in the course of the 1920s. The local ChK/OGPU helped the party leaders fend off challenges from party "oppositions." They helped local party leaders promote regional economic plans. When the five-year plan descended into crisis and the centre demanded complete and unquestioning fulfilment, the political police began to defend the regional party leaders from the pressures of the command-administrative order, in contradiction of the spirit and substance of directives from their superiors in Moscow. The local political police plenipotentiary was a central member of the emerging Obkom "family circle" or "clique." His key function was to find scapegoats for problems of production, to find "wreckers" and "saboteurs" in order to evade investigation from the centre. When Moscow nevertheless uncovered these tactics in 1937, the vestiges of dual subordination were eliminated in favour of strict subordination to Moscow. The effect imposing an antagonistic political police on the local party organs was to destabilise politics in the regions, and to make terror a fact of everyday political life.

4. G. Leggett, op. cit.: 123-124, 351 .

5. Technically, the head of the regional political police belonged in the Central Committee nomenklatura. At least in the Urals region, the appointment was made by the Obkom, and subsequently approved by the Central Committee. 


\section{ChK/GPU and the local "oppositions"}

In the Urals region, the relationship of the regional party leaders and the Cheka/ OGPU tended from the outset to be mutually supportive. The regional party organs had responsibility for the selection of political police officials and they paid their wages. These officials were, in turn, inclined to protect party officials from challenges to their rule. But it was in the course of defending party leaders in local power struggles ("skloki") that the relationship was initially forged.

On the eve of the February Revolution, there were approximately 24,000 members in the Bolshevik underground. By the end of the Civil War, over 700,000 new members had joined the now ruling party. ${ }^{6}$ As a consequence of the colossal rate of growth, the general quality of officialdom was extremely low in terms of basic literacy, administrative skills and even loyalty to the party. Particularly in the immediate aftermath of the October seizure of power, many had joined the Bolshevik party in order to take advantage of the privileged access to food, housing and jobs accorded to members. At the very height of the Civil War, in 1919, the party leadership had felt compelled to initiate a purge of corrupt and "morally dissolute" members. The long struggle against the White Armies, combined with political training in the army did reinforce loyalty to the party, and literacy campaigns raised educational levels, but corruption and incompetence remained serious problems in administration.

Ironically, the more talented, experienced and ambitious party members presented a far more troubling problem. This narrower, though still substantial, group competed for a limited number of leading positions. Not everyone could be a provincial party committee secretary, a department head in a commissariat, even a district party committee secretary or village soviet chairman. Throughout the growing party and state bureaucracy, officials wanted to give orders, not to take them. As the bureaucracy absorbed new cadres, struggles for power erupted at all levels in the drive to capture the "responsible positions" within and among organisations. Local officials were locked in struggle with cadres sent in from Moscow. New recruits to the party refused to accept the seniority of members with underground experience. Soviet executive committee chairmen refused to follow the directives of the party committee secretaries, local economic councils (sovnarkhozy) fought with local trade unions. ${ }^{7}$ In part, the struggles were fuelled by policy differences among Politbiuro leaders. Policy disputes were a matter of principle for some Bolsheviks, but for others they were an excuse to attack the position and authority of their opponents. No senior official could be sure that one

6. T. H. Rigby, Communist party membership in the USSR, 1917-1967 (Princeton, N. J., 1968): 7-8, 52 .

7. On the variety of conflicts in party organizations, see Rossiiskii Gosudarstvennyi Arkhiv Sotsial'no-Politicheskoi Istorii (RGASPI), f. 17, op. 34, d. 110 Materialy k XII s"'ezdu RKP(b) o sostoianii mestnykh partiinykh organizatsii, 11. 7-35, Svodki o sostoianii mestnykh partiinykh organizatsii. 
of his colleagues was not conspiring to take his place. The struggles (skloki) pervaded the apparatus, paralysing entire organisations throughout the country.

The Urals regional organisation was no exception. In the first years after the revolution, the regional party leaders constantly complained to the Central Committee of the poor quality of cadres, drunkenness, abuses of power, but also of insubordination and power struggles. In 1918, the discussion of the Brest-Litovsk Peace deeply divided the regional party as almost half the organisation opposed the Treaty. Several years on, little had improved. Drunkenness and abuses of power remained just as common as before. Meanwhile, the struggle with the White Army had left much of local industry in ruins and much of the countryside was in the midst of famine. Just as there was a great need for decisive action, a new controversy - this time on the role of trade unions - split the organisation. In advance of the X Party Congress, the "Workers Opposition," had gained significant support in the larger urban party organisations. Though they were defeated in most votes in the region, and at the party Congress, the local leaders of the Opposition, Sergei Mrachkovskii and Nikolai Ufimtsev, refused to stop their attacks on the regional party organisations. ${ }^{8}$ A year later, Mrachkovskii and Ufimtsev led a new attack on the regional leadership, this time in a debate on the internal party situation. ${ }^{9}$ Again they were defeated, and again they continued their attacks. The ban on factions, instituted at the X Congress, had little immediate effect. They withdrew into their base, in the regional metallurgists trade union in order to plan their next move. ${ }^{10}$

For nearly five more years the same core group of "oppositionists" railed against the regional party organisation both within regular party meetings and in public demonstrations. But thanks to the services of the OGPU, they were less a threat than an irritation. OGPU compiled an exhaustive list of active oppositionists and tailed all of them..$^{11}$ They regularly reported all incidents of "oppositionist activity" to the regional party leadership and the regional control commission. Regional party officials then passed the information to the party secretariat, to Stalin. ${ }^{12}$

And yet, should we not assume that the OGPU was acting on behalf of Stalin rather than the regional organisations? And that the struggle against oppositions in the regions was only a part of his struggle against his own political opponents?

8. Tsentr Dokumentatsii Obshchestvennykh Organizatsii Sverdlovskoi Oblasti (TsDOO SO), f. 41 Istpart, op. 1, d. 134 Obrashchenie Ekaterinburzhskoi organizatsii RKP(b) ko vsem organizatsiiam i kommunisticheskim iacheikam Urala s pryzyvom podderzhivat' leninskuiu platformu i t. d. $1921 \mathrm{~g} ., 11.25-33$.

9. TsDOO SO, f. 1494 Uralbiuro TsK, op. 1, d. 34 Tsirkuliary i telegrammy za podpisiami sekretarei TsK RKP(b) po voprosam partiinoi raboty i partiinym kadram, 11. 42-43.

10. TsDOO SO, f. 1494 Uralbiuro TsK, op. 1, d. 78 Politicheskii obzor i otchety o rabote Ural'skogo biuro TsK RKP(b) dekabr' 1921-avgust 1922,1. 75.

11. The OGPU list of the 115 leaders of the Left Opposition in the Urals (1927) is found in TsDOO SO, f. 4 Obkom, op. 5 1927, d. 30 Spravki, dokladnye telegrammy, akty doprosov o bor'be Ural'skoi partiinoi organizatsii s oppozitsiei, 11. 130-132.

12. Ibid., 11. 67, 76 . 
Wasn't the local OGPU taking orders from Stalin through the central political police organs? What is striking is the confluence of the interests of Stalin and the regional leaders. At the time Stalin was named General Secretary, the main subject of correspondence between the Secretariat and regional party organisations was the struggles for power (skloki). ${ }^{13}$ Regional party secretaries constantly appealed to the Secretariat for assistance in the resolution of power struggles. There is little evidence to suggest that the Secretariat or Stalin was directing the struggle against oppositions, or enforcing conformity to any set of policies or "political line."

Instead the Secretariat generally encouraged the resolution of such conflicts locally. ${ }^{14}$ The simplest way to do so was to clarify and strengthen the hierarchy of existing party and state organisations, and reinforce the powers of the current "bosses," most notably, the network of local party secretaries. The resolutions of the XII Party Congress (April 1923) strengthened the role of party secretaries in selecting "responsible workers of the soviet, economic, co-operative and professional organisations" in their regions. In effect, the party secretaries became the main arbiters of the struggles, with the power to remove officials who refused to submit to their decisions. Stalin further supported regional organisations by encouraging them to label as anti-party "group struggle" any attempt to challenge to their rule. This he did by advocating the restriction of intra-party democracy.

At the XIII Party Congress, the Left Oppositions demanded a strengthening of intra-party democracy including such measures as a restoration of elections to party organs (party committee bureaux). ${ }^{15}$ To any party secretary, the implications of such a program were immediately clear. They would be open to attack from any disgruntled party member, to say nothing of groups of "comrades" who might want to topple them from their leadership posts. Stalin told them what they wanted to hear.

He insisted that the Opposition was promoting not democracy, but a "freedom of group struggle" (svoboda gruppirovok) that would be fatal in the "current conditions" of the New Economic Policy:

13. See for example, RGASPI, f. 17, op. 67, d. 6 Protokoly i pis'ma Astrakhanskogo gubkoma VKP(b) i otvetstvennykh rabotnikov o vystupleniiakh oppozitsii, 1. 16; d. 109 Vypiski protokolov zasedanii i zakrytye pis'ma Kostromskogo gubkoma RKP(b), 11. 168-169; d. 249 Perepiska s TsK KP(b)U i dokladnye zapiski, spravki i drugie dokumenty po voprosam sostava, sostoianiia i raboty partiinykh organizatsii, o vystupleniiakh oppozitsii,1. 68.

14. KPSS $v$ rezoliutsiiakh i resheniiakh s"ezdov, konferentsii i plenumov TsK (Moscow, 1984): 74,99 . The research of the Information department suggests that the regional secretaries were not shy about asserting those powers. RGASPI, f. 81 Lichnoe delo Lazara Moiseevich Kaganovicha, op. 3, d. 69 Dokladnye zapiski, spravki i drugie dokumenty orgraspredotdela TsK RKP(b) po voprosam organizatsionno-partiinoi raboty, 11. 189-191 Spravka Informatsionnogo otdela "O rukovodstve sovetskoi, khoziaistvennoi, kooperativnoi i professional'noi rabote so storony partkomov". Kaganovich was the chairman of the Organisation-Distribution department at the time.

15. See Evgenii Preobrazhenskii's speech to the XIII Party Congress. Trinadtsataia konferentsiia RKP(b). Stenograficheskii otchet (Moscow, 1924): 106-107. 
"If we were to permit the existence of group struggle, we would destroy the party, turn it from a monolithic, united organisation into an alliance of groups and fractions. It would not be a party, but rather the destruction of the party."16

The "retreat" from democracy proved to be very durable. Party secretaries were pleased to repeat Stalin's phrases about the importance of party unity and use them to legitimise the repression of any challenge to their power. ${ }^{17}$ And as the regional secretaries took action against all those who engaged in "group struggle," they made organised opposition to Stalin almost impossible.

Documents of regional and central archives leave no doubt that Stalin and the central party leadership were kept well informed of the activities of oppositionists and others who challenged the power of regional secretaries. ${ }^{18}$ The local OGPU passed information to the okrug control commissions, which sent regular reports to the regional Control Commission. ${ }^{19}$ The commissions began to expel oppositionists from the party in the autumn of 1926.20 Was the local OGPU, in this instance, directed by the regional party organs, or by the central OGPU, the central leadership, if not by Stalin himself? Well into the late 1920s, these relationships remained close, and mutually reinforcing. The regional archives suggest that the regional party was directing the local OGPU, with the approval, or at least the knowledge, of the centre. But in the early years of the "Stalin revolution" evidence emerges of local OGPU actions, directed by the regional party, of which the centre would not have approved.

\section{Ibid.: $93,100-101$}

17. For such a statement from the Urals region see the resolution of the Obkom biuro on intraparty democracy (December 17, 1925) TsDOO SO, f. 4 Obkom, op. 4 1926, d. 47 Doklad, itogi obsuzhdeniia diskussii XIV s"'ezda VKP(b) v partiinykh organizatsiiakh Urala, 1. 101.

18. See for example RGASPI, f. 17, op. 67, d. 249, 1.68 (Ukraine); d. 285 Zakrytye pis'ma i dokladnye zapiski Ural'skogo obkoma RKP(b), raikomov i okruzhkomov RKP(b) oblasti, orgraspredotdela i instruktorov TsK RKP(b) ob ekonomicheskom i politicheskom polozhenii oblasti, o sostoianii i deiatel'nosti partorganizatsii, perepiska po voprosam ucheta kommunistov i dr. sentiabr' 1925-noiabria 1925, 1. 102 (Urals); d. 378 Dokladnye zapiski, spravki informotdela, instruktorov TsK i Tverskogo gubkoma VKP(b) o sostoianii i rabote gubernskoi partiinoi organizatsii, o vypolnenii postanovlenii TsK po dokladu gubkoma, ob obsledovanii postanovki massovoi raboty na predpriiatiiakh Tverskogo khlebo-bulochnogo tresta, ob oppozitsionnykh vystupleniiakh i dr. oktiabr' 1926- ianvaria 1928, 1. 192 (Tver'); d. 193 Doklady i zakrytye pis'ma Irkutskogo gubkoma VKP(b) i drugie dokumenty ob ekonomicheskom i politicheskom polozhenii gubernii, o rabote partiinoi organizatsii, o fraktsionnoi deiatel'nosti oppozitsii, o vydvizhenii rabochikh i krest'ian i vovlechenii y obshchestvennuiu rabotu i drugie, 1.98.

19. TsDOO SO, f. 4 Obkom, op. 5 1927, d. 30 Spravki, dokladnye, telegrammy, akty dokladov o bor'be Ural'skoi partorganizatsii s oppozitsiei, 11. 77, 86-104.

20. Ibid., 11. 133-135; Dva goda raboty: Materialy k otchetu Ural'skogo Obkoma VKP(b) k VIII oblastnoi partkonferentsii (dekabr' 1925 g.-noiabr' 1927 g.) (Sverdlovsk, 1927): 131. 


\section{OGPU and the plan}

In the mid-1920s, the regions exerted considerable pressure on the centre to expand levels of investment and construction. Regional leaders perceived that central investment in the local economy was the key to regional economic health. Modernisation of the existing capital stock and new construction improved the efficiency of production, which increased the ability to sustain the competition for markets and sales. In the context of the New Economic Policy, with its emphasis on commercial principles (khoziaistvennyi raschet), uncompetitive - and thus unprofitable - industries were shut down. Profitable ones brought the regions tax income, employment and the potential for further reinvestment and growth. Enterprise profit was an important part of capital investment, but Soviet industry was still too weak to generate internally a significant rate of growth. Central investment, on the other hand, could give a relatively quick competitive advantage to its beneficiaries. ${ }^{21}$

In this context, the five-year plan was a matter of particular concern for the regions. They understood that five years of central investment would have a profound impact on the state and status of the regional economy. As the five-year plan emerged from its preliminary outlines toward its final version, it was the object of ever-greater controversy and conflict. Each region tried to prove that its own contribution was indispensable, that it could produce better, faster and less expensively than the others were. In the process, interregional competition created further upward pressure on the levels of investment and construction. It also exacerbated existing tensions between those who believed in a revolutionary potential of the planned economy and those who understood the essence of planning to be thorough and careful calculation. Within the regions, the fear of losing five-year plan investment to competing regions drove support for ambitious proposals, but it also led to conflicts within the regional leadership and between the regional party and economic officials over the capacity of regional economy to achieve them. In the centre, the enthusiasts of high tempo industrialisation, led by Stalin, were able to manipulate these conflicts for their political ends. The Shakhty trial and the campaign against the "Right danger" - both signals to attack opposition to high tempos - served not only Stalin's desire to gain control of the central leadership, but also the determination of many regional leaders to promote ambitious plans.

Within the party leadership, there was considerable support for testing the upper limits of investment and growth, but there was also concern for the potentially disruptive effects of an over-aggressive industrialisation program-in particular, the danger of a break with the peasantry. Within the central economic and planning organs the issue of the tempo of industrialisation was the subject of ever-sharper conflicts. VSNKh continued to be the most ambitious planner, while Gosplan,

21. James R. Harris, The Great Urals: Regionalism and the evolution of the Soviet system (Ithaca, NY, 1999): chs. 2-3. 
NKFin and NKZem fought to restrain tempos. Each group was convinced of the dire consequences to the economy of a failure to accept their plans. At the same time, a more important set of conflicts was emerging within each of the economic organs. The debates had brought forth a division between non-party specialists and their party colleagues, between "bourgeois" specialists and their soviet-trained counterparts.

In the Urals, regional party leaders were absorbed with the task of maximising industrial investment and growth, but they could not agree on how far or how fast they should proceed. They disagreed as to how ambitious regional plans could be, how hard they could push the centre for investment in the Urals and how hard they could push local trusts and enterprises to produce. Enterprise directors were not opposed to high "tempos," but the accompanying pressures on their performance disturbed many. "Bourgeois" specialists were perhaps the most troubled by the demands for improved efficiency and the sudden acceleration of industrialisation. As the question of sustaining growth rates became a matter of blinkered determination for many Bolsheviks, some specialists found themselves unable, or unwilling, to fulfil their roles. And yet the steady advance of Ukraine's ambitions and the danger of being passed over for first five-year plan investment lent new urgency to the issue. Members of the Obkom lost patience with any hesitation to meet the Ukrainian threat head-on.

In April 1927, the central party apparatus began to take an active interest in local resistance to rising plan targets. The Obkom received a letter from the Central Committee Information Department requesting information on "incidents of opposition to rationalisation and [the region's] methods of struggling with it."22 As in the Urals oblast', some members of the central leadership took a dark view of local resistance. That same month, the OGPU took a newly active interest in "sabotage" at the factory. It is unclear on whose initiative the OGPU was drawn into the matter, ${ }^{23}$ but on April 7, a letter sent to okrug leaders warned that

"a sudden increase of accidents, explosions and fires at enterprises and construction sites of all-union significance has been observed [...] Taking into account the seriousness of the situation, the organs of the OGPU have been given a broader range of powers, including both the defence of the enterprises themselves and punitive functions [...].

The organs of the OGPU have been given directives to remove from all the most important state enterprises and construction sites politically unreliable elements as well as refugees, former white guardists, returned emigrants and others [...]."24

22. TsDOO SO, f. 4 Obkom, op. 5 1927, d. 34 Perepiska s Tsentral'nym Komitetom o bor'be s oppozitsiei, 1. 64.

23. The protocols of Central Committee organs, including the Politbiuro and the Secretariat, were not helpful in this regard.

24. TsDOO SO, f. 4 Obkom, op. 5 1927, d. 34 Perepiska s Tsentral'nym komitetom o bor'be s oppozitsiei, 1. 55 . 
This letter was relayed "to all secretaries of okrug party committees, chairmen of okrug executive committees and chairmen of okrug trade union councils" by F. I. Lokatskov, the chairman of the Urals oblast' executive committee, and two other members of the Urals Obkom. Lokatskov led an oblast' level commission on cost reductions in industry, and he used this position to pressure okrug officials to get results from the factories "at all costs." 25 In the months that followed, attacks on directors and technical specialists increased. There were no arrests or accusations of "counter-revolutionary activity," but acts of intimidation were common. Particularly in cases where efficiency targets were substantially underfulfilled, okrug and raion leaders commonly accused factory officials of resisting directives or labelled them as incompetents and took measures to fire them. ${ }^{26}$

The tide had yet to turn entirely against the directors and technical specialists. Both in the Obkom and the centre there were those who believed that repression would only make targets harder to achieve. It was ultimately Stalin who, in early 1928 , broke the tensions between those who promoted a hard and soft line. Some time in February, he had received a letter from the Azovo-Chernomorskii krai describing an alleged criminal conspiracy of old specialists in the coal industry of the Donets basin (Donbass) to disrupt the Soviet fuel supply on behalf of foreign interests. After the letter was presented to the Politbiuro and discussed with members of the OGPU (Ianson and Menzhinskii), a top-level delegation was sent to the Donbass to "make recommendations for practical measures that can form the basis for the work of a Politbiuro commission." 27 The primary recommendation of the Commission is well known: the organisation of a show trial-the Shakhty trial.

At the beginning of April, a Central Committee plenum met to discuss the Shakhty affair. The plenum showed the continuing division of opinion on economic policy. In a speech introducing the issue, A. I. Rykov observed that "since the conspiracy was uncovered, some party comrades have thought that the affair was blown out of proportion." Rykov insisted that, as the investigation proceeded, it was becoming clear that the seriousness of the conspiracy was, if anything, initially underestimated. Some subsequent speakers, including A. A. Zhdanov of Nizhnii Novgorod and A. A. Andreev of the North Caucasus, enthusiastically agreed that there were counter-revolutionary elements among their economic managers. ${ }^{28}$ Other delegates, including K. V. Sukhomlin of Ukraine and M. Oshvintsev of the Urals, warned about the dangers of whipping up hostility to managers. Sukhomlin

25. TsDOO SO,f. 4 Obkom, op. 5 1927, d. 10 Protokoly biuro Obkoma, 11. 9, 53, 107-109, 339, 364. These are all resolutions of the commission critical of okrug party committees for their failure to ensure reductions in production costs.

26. See for example Gosudarstvennyi Arkhiv Sverdlovskoi Oblasti (GASO), f. 94-r Uralmet, op. 4 1926, d. 9 Perepiska predsedatelia Pravleniia Uralmeta s Glavmetallom i promyshlennymi predpriiatiiami o finansirovanii i stroitel'stve zavodov, 11. 3, 10, 13, 20, 38, 54, 80-87, 109, 112-116.

27. RGASPI, f. 17 Tsentral'nyi komitet, op. 3 Protokoly Politbiuro, d. 676 Protokol \#14, 7 marta 1928, 1. 22 Ob ekonomicheskoi kontrrevoliutsii v iuzhnykh raionakh ugol'noi promyshlennosti; d. 677 Protokol \#23, 15 marta 1928, same title.

28. Ibid., 11. 82-85 (Zhdanov), 133-138 (Andreev). 
suggested that creating a political campaign on the Shakhty issue could "bring harm, make matters worse." 29 Oshvintsev agreed, explaining that many managers were already so frightened that they spent much of their time getting written approval of all their actions and had little time left to oversee production. ${ }^{30}$

The Plenum ended in a stalemate between the advocates of repressive action against old specialists and non-party managers and those who sought to prevent a campaign against them. Despite Stalin's open advocacy of a "class struggle" of old and new economic officials, ${ }^{31}$ the resolutions of the Plenum showed clear evidence of a compromise between the conflicting groups in the leadership. ${ }^{32}$ The resolutions neither afforded protection for managers and specialists, nor signalled an attack. Party leaders in the regions were essentially free to proceed as they saw fit. Consequently, existing tensions went unresolved.

In the Urals, conflict over the tempo of industrialisation intensified in the course of 1928. The need for dramatic action was apparent. It was generally perceived that the majority of new investment was going to Ukraine. An article in the VSNKh newspaper had observed that with projected investment of over 100 million rubles in the Southern Steel Trust, Ukraine could significantly expand production, but that projected investment of 50 million rubles in the Urals might not even prevent production in the Urals from shrinking. ${ }^{33}$ Urals leaders increasingly felt the necessity to show that regional industry could provide a higher rate of return in order to avoid losing projects to Ukraine and other regions. They had hesitated to pressure local managers and planners to revise their plans, but as Ukrainian industry advanced, the mood began to change.

In the fall of 1928, in connection with an investigation of wrecking in the gold and platinum industries in the USSR, the Urals OGPU uncovered a local group of "counter-revolutionary specialists." ${ }^{4}$ The new Oblast' Executive Committee chairman I. D. Kabakov, among others in the Urals leadership, made much of the

29. RGASPI, f. 17 Tsentral'nyi komitet, op. 2 Plenumy, d. 344 Stenogramma Plenuma TsK i TsKK, 6-11 aprelia 1928, t. 1,1.21

30. Ibid., 1. 122.

31. RGASPI, f. 17 Tsentral'nyi komitet, op. 2 Plenumy, d. 347 Stenogramma Plenuma TsK i TsKK, 6-11 aprelia 1928, t. 4, 11. 34-35. Stalin was effusive in his praise of Andreev's "truly revolutionary speech." He insisted that "we must arm new specialists in such a way that they will be certainly victorious in a struggle with old specialists."

32. The number of party members among economic managers was also to be rapidly increased. KPSS v rezoliutsiiakh, vol. 4 (Moscow, 1984): 328.

33. Torgovo-promyshlennaia gazeta (July 7, 1928).

34. Gosudarstvennyi Arkhiv Administrativnykh Organov Sverdlovskoi Oblasti (GAAO SO), f. 1, op. 2 Lichnye dela, d. K-12238 O kontr-revoliutsionnoi vreditel'skoi organizatsii v zolotoplatinovoi promyshlennosti SSSR. All files from GAAO SO (the regional FSB archive) consist of transcripts of interrogations. Such a source must be approached with extreme caution. Given the brutality of secret police methods and the propensity to demand confessions to imaginary crimes, the initial impulse of the researcher is to assume that the transcripts represent the ideas of the interrogators rather than the interrogated. However, judging from a broad cross section of files, from the mid-1920s through the Great Terror, this seems to be much less true of interrogations that open a given investigation. For example, at the outset of the Uralplatina 
discovery-which came to be known as the "Uralplatina affair." At the November 1928 Central Committee plenum, Kabakov announced that documents found on local specialists-geologists-showed they had long hidden reserves not only of gold and platinum, but also of coal and ores. ${ }^{35}$ The Urals State Geological Surveying Administration (Ural'skoe Gosudarstvennoe Geologorazvedochnoe Upravlenie UGGRU) became a special target for political pressure from the Obkom. Urals geologists were told to find new reserves of metals, ores and especially cokeable coal in an extremely short period. Significant proven deposits had the potential to substantially reduce the cost of metal production by reducing-or eliminating-the need to import coal from Siberia. Senior geologists scoffed at the demands. M. S. Volkov, the technical director of UGGRU later described his senior colleagues as scholars with their own research agendas, unhappy being compelled to serve the immediate needs of industry. They were most offended by the demands for immediate results. They knew that surveying the requested areas would require much more financing, cadres, and time, than they were given. They were quick to call the new tasks "impossible" and "absurd." ${ }^{36}$ The Obkom was equally quick to respond. It replaced the administration of UGGRU with party members, and encouraged the Soviet-trained geologists to criticise their bosses. Shortly thereafter, the new UGGRU administration removed senior geologist D. F. Murashev for submitting an article to the press suggesting that Urals copper reserves were "exaggerated." Administration officials accused him of "attempting to discredit the Urals as a powerful base for the Soviet copper industry." The Obkom had made it clear that giant new "finds" would be rewarded. Anything else would be viewed as an attempt to "reduce the Urals to the status of a second-rate mining centre in the USSR." ${ }^{37}$ The Uralplatina affair was a turning point. In one sense, the regions were promoting Stalin's line on class struggle. In another, they were deceiving Moscow about the real state of the local economy.

The "Uralplatina affair" was the most important, but not the only case used by members of the Obkom to put upward pressure on regional plans. In the fall, incidents of open resistance to tempos were the subjects of trials in many of the

investigation, OGPU interrogators asked relatively open-ended questions. Responses were plausible in commonsense terms and the events they described can often be verified against other credible sources. Those interrogated were not under pressure to confess to fantastic charges such as spying for foreign governments or plotting the assassination of Soviet leaders, at least not until the summer of 1937. Of course, even the early investigations featured forced confessions. The transcripts generally begin with an initial denial of "membership in an underground Trotskyist organisation" and proceed days or weeks later to a confession of just that. Once that "confession" had been made, Trotskyism became a vague label, a frame for the description of concrete events and actions: the underfunding of geological surveys, the masking of poor results and so on. It was not until interrogators were well into an investigation that they began simply to demand confessions that conformed to an existing "master text".

35. RGASPI, f. 17 Tsentral'nyi komitet, op. 2 Plenumy, d. 385 Stenogramma plenuma Tsentral'nogo Komiteta, 16-24 noiabria 1928, t. 4, 11. 144-145.

36. GAAO SO, f. 1, op. 2 Lichnye dela, d. 43927 Delo Volkova, Mikhaila Semenovicha, 1. 64.

37. Ibid., 11. 7, 23-25, 64 . 
Urals main industrial districts, including Kushva, Bakal, Solikamsk and Zlatoust. ${ }^{38}$ Many of those who opposed existing efficiency targets or disputed the realism of targets for industrial growth were intimidated into silence. V. P. Krapivin, the technical director of the Urals Metallurgical Trust, promoted the plans of the Trust before central organs despite his firm conviction that the construction schedules and advances in efficiency were exaggerated. ${ }^{39}$

The aftershocks of the Shakhty affair appear to have had the same effect throughout the Soviet Union. M. A. Solovov, a prominent figure in the Urals Planning Commission, later recounted how he had "felt the general lack of faith in the tempos of the five-year plan in the corridors of the (April 1928) Gosplan Congress. ${ }^{40}$ At the end of September, Politbiuro member N. Bukharin published his "Notes of an economist" in Pravda, warning of the potential dangers to economic equilibrium presented by the control figures. ${ }^{41}$ Meanwhile, in the regions, there was a sense of desperation about the control figures. The figures for 1928-1929 were to constitute the first year of the five-year plan. Failure to establish a favourable relative share of investment in the 1928-1929 figures could undermine a region's ambitions for a much longer period. Thus, tensions in the regions were also driven to a head.

By mid-October, probably on Stalin's initiative, the press began to print articles warning of a "Right deviation" in the party. At the November 1928 Central Committee, Sovnarkom chairman A. I. Rykov attempted to smooth over differences of opinion in his speech opening the plenum. He admitted that the control figures had left a "huge mass of unsatisfied demands," but he argued against "creating a fetish for tempos" - the economy could not sustain a consistent growth of tempos, or even the maintenance of the existing rates of growth. ${ }^{42}$ Nevertheless, many delegates both from the regions and the centre insisted on both higher tempos and a much harder line on the "Right danger." They took the podium with criticism of inadequate funding for projects under their jurisdiction: tempos had to be raised, and those who opposed them removed from the party. ${ }^{43}$ At the subsequent XVI Party Conference (April 1929), regional delegates specifically linked cuts to proposed projects with the leaders of the "Right opposition." N. B. Riazanov of the Institute of Marx and Engels joked that "every speaker ends his presentation with "Give us a factory in the Urals and to hell with the Right!" "Build us a power station

38. Ural'skii rabochii (September 1, October 23, 1928).

39. GAAO SO, f. 1, op. 2 Lichnye dela, d. 7504 Delo Solovova, Mikhaila Aleksandrovicha, 11. 66-67.

40. Ibid., 11. 19-20.

41. Pravda (September 30, 1928).

42. RGASPI, f. 17 Tsentral'nyi komitet, op. 2 Plenumy, d. 377 Stenogramma plenuma Tsentral'nogo komiteta, 16-24 noiabria 1928, 11. 23-24, 63-64.

43. RGASPI, f. 17 Tsentral'nyi komitet, op. 2 Plenumy, d. 381 Stenogramma plenuma Tsentral'nogo komiteta, 16-24 noiabria 1928. See for example the speeches of R. I. Eikhe (Siberia) ch. 1, 1. 15; F. I. Goloshcheikin (Kazakhstan) ch. 1, 11. 25-26; V. Ia. Chubar' (Ukraine) ch. 2,1.54; S. I. Syrtsov (Siberia) ch. 2, 1. 128; M. M. Khataevich (Middle Volga) ch. 2,1. 148. 
and to hell with the Right!"' 44 Regional leaders not only accepted Stalin's campaign against the Right, they encouraged it.

During the campaign, many regional party and economic officials still refused to accept cuts to their plans. When a new proposal was rejected, or financing to an existing project reduced, these officials commonly sought to overturn the decision by accusing its authors of "disorganising" the economy. In the spring of 1929, funding for the construction of the Uralmash plant was cut from 6.5 million to 2 million rubles, and then in May instructions were received by telegram from Glavmetall to suspend construction altogether. Upon receipt of the telegram, a meeting of the Uralmash party cell was convened. It resolved to "declare the instructions of Glavmetall incorrect and achieve their reversal." 45 The director of Uralmash, A. P. Bannikov, then headed to Moscow. He denounced the Glavmetall instructions in his meetings with party leaders, members of the VSNKh Presidium and the chairman of the Workers and Peasants Inspectorate S. Ordzhonikidze. ${ }^{46}$ According to S. A. Khrennikov, a member of the Collegium of Glavmetall, regional officials frequently presented exaggerated, excessively expensive, incomplete and unworkable plans to central organs and leapt to accusations of "wrecking and sabotage" if the plans were rejected..$^{47}$ Beginning in the summer of 1929, the OGPU led a wave of arrests of economic officials accused of "wrecking." In the process of its "investigations," it received masses of denunciations of central officials from the regions..$^{48}$ In this way, the work of the regional OGPU contributed directly to Stalin's victory over the Right Opposition, and the last obstacle to the assumption of uncontested personal power, but not all of the work of the Urals political police would have won Stalin's personal approval. The regional leadership was also using the local OGPU to mislead the centre and to manipulate central policy in its favour.

In the competition for the first five-year plan investment, the lack of local supplies of cokeable coal had been the single gravest argument against the development of the Urals as a metals and machine building centre. The importation of coke from the Kuznetsk basin in Western Siberia pleased neither Moscow nor the Urals given the high cost of transportation. Coking experiments on Urals coal had been conducted throughout the 1920s without producing clear results. By the late 1920s, when the Urals version of the first five-year plan was under

44. Shestnadtsataia konferentsiia Vsesoiuznoi Kommunisticheskoi Partii (bol'shevikov). Stenograficheskii otchet, 23-29 aprelia $1929 \mathrm{~g}$. (Moscow, 1929): 102.

45. A. I. Busygin, Pervyi direktor (Sverdlovsk, Sredne-ural'skoe knizhnoe izd., 1977): 64; G. A. Unpelev, Rozhdenie Uralmasha, 1928-1933 gg. (Moscow, Izd. sotsial'no-ekonomicheskoi literatury, 1960): 24.

46. A. I Busygin, op. cit.: 66.

47. Material $k$ otchetu TsKK VKP(b) XVI s' 'ezdu VKP(b), sostavlennyi OGPU (k dokladu tov. Ordzhonikidze) (Moscow, 1930): 50, 53.

48. GAAO SO, f. 1, op. 2 Lichnye dela, d. 43927 Delo Dunaeva, Borisa Sergeevicha (member of the Presidium of the Urals Oblsovnarkhoz), 1. 157; d. 43927 Delo Girbasova, Petra Afanas'eva (technical director of the Urals Mining Trust), 11. 136-137; d. 7504 Delo Gassel'blata, Vitaliia Alekseevicha (technical director of Magnitostroi), 1. 32; G. A. Unpelev, op. cit.: $24-26$. 
consideration in central economic organs, regional party leaders exerted intense pressure on local geologists and metallurgists to produce favourable results. Urals leaders were concerned that new investment in coal production would go to the Moscow or Don basins. ${ }^{49}$ The pressure resulted in a split between senior specialists trained before the revolution and the new cadre of Soviet-trained specialists. ${ }^{50}$ The former resisted the pressure and the latter took the opportunity to discredit their bosses by exaggerating the success of their experiments. ${ }^{51}$ In the summer of 1930 , I. D. Kabakov, now oblast' party first secretary, wrote in a letter to the head of the Urals Coal Trust:

"The issue [of the coking of Urals coal] is not looking good. Not in the sense that Kizel [a Urals coal basin] coke can't be used for metal production, but rather in the sense that people out there have tried to discredit (kakaia-to ruka sdelala vse dlia togo, chtoby diskreditirovat') the coking of Kizel coal. The issue is being investigated, and at the present stage it's clearly a criminal affair (prestuplenie na litso). In all probability it's the work of specialists-of course those hostilely oriented towards us. It's better not to raise a fuss. We'll finish the investigation and everything will be clear. We can hope to extricate ourselves ( $o b$ etom dele vykruchivat'sia) and not permit the discreditation of Kizel coke." 52

Within a couple of months, a group of Urals metallurgists and geologists were arrested and charged with "criminally delaying the development" of the regional coal industry. ${ }^{53}$ The affair was kept sufficiently quiet such that Moscow never saw fit to question the results of the coking experiments. In the next five years, hundreds of millions of rubles were spent developing mines in the Kizel basin and building coking plants-though Kizel coal never was cokeable..$^{54}$

A similar scenario was played out in the Urals copper industry in 1931 when local officials were preparing the first version of the regional second five-year plan. Huge copper reserves were being discovered in Kazakhstan, 55 and Urals officials

49. GAAO SO, f. 1, op. 2 Lichnye dela, d. 43927 Delo Girbasova, Petra Afanas'evicha, 11. 136137.

50. GAAO SO, f. 1, op. 2 Lichnye dela, d. 43927 Delo Volkova, Mikhaila Semenovicha, 11. 6264. The transcripts of the interrogations of Volkov, Girbasov and others are included in the same delo.

51. The process follows a pattern distinctly similar to that of other professions. See for example Sheila Fitzpatrick, "Cultural revolution as class war," Susan Gross Solomon, "Rural scholars and the cultural revolution," and George M. Enteen, "Marxist historians during the cultural revolution: A case study of professional in-fighting," in Sheila Fitzpatrick, ed., Cultural revolution in Russia, 1928-1931 (Bloomington, 1978).

52. TsDOO SO, f. 4 Obkom, op. 8 1930, d. 102 Spravki, protokoly rassledovaniia organov OGPU po Uralu, raikomov i gorkomov VKP(b) o faktakh klassovoi bor'by i vreditel'stva na predpriatiiakh oblasti, 1. 54. One can assume that Shakhgil'dian, the head of the Urals Coal Trust, was a party to this affair. He and Kabakov were reputed to be very close friends until they were both arrested in 1937. GAAO SO,f. 1, op. 2 Lichnye dela, d. 22861 Delo Sedasheva, 1. 39; d. 17368 Delo Kabakova, Ivana Dmitrievicha, 1. 75.

53. Ibid., d. 43927 Delo Volkova; d. 43935 Delo Anitova, Sergeia Ivanovicha.

54. To this day, despite steady advances in coking technology, neither Kizel coal, nor any other Urals coal is considered efficiently cokeable. 
were determined not to lose investment capital to their southern neighbour. Copper production was crucial to the production of alloys, construction materials and machine building and it promised the development of subsidiary chemical production based on by-products. The Urals was hoping for over a billion rubles of investment in its non-ferrous metals industry in the second five-year plan. ${ }^{56}$ Rather than admit that the regional geological surveying administration still had no clear data on ore reserves, local leaders directed the OGPU to pressure the administration to fake firm conclusions in a presentation to the government. ${ }^{57}$ Construction was approved (though not the full billion rubles requested) and when the plants were completed, the ores proved neither to be of the quantity nor of the quality promised in the plan..$^{58}$ Now the pattern of deception was confirmed. In the early 1930 s the OGPU was dually subordinated only in theory. In practice, it served the regional party and promoted its interests at the expense of those of the centre. The pattern only deepened in the following few years.

\section{OGPU/NKVD and blameshifting}

The fantastic ambitions of the first five-year plan drove the economy into a state of chaos. Almost no plan targets were fulfilled and the centre and regions bickered about who was at fault. Nevertheless, when by 1931 the attention of planning organs shifted to the second five-year plan, regional organs once again proposed vast programs of investment and construction. ${ }^{59}$ But this time, the centre refused to accept them. Three times the general plan was revised, each time reducing projected targets. Even more disturbing to the regions was the fact that these reduced targets would be enforced. No excuses would be accepted for anything less than $100 \%$ fulfilment.

A more "moderate" plan was hardly of any solace to the regions. Targets for construction and production were reduced, but projected financing was reduced even further. Calls for "iron discipline before the budget of the proletarian

55. Rossiiskii Gosudarstvennyi Arkhiv Ekonomiki (RGAE), f. 4372 Gosplan SSSR, op. 31 1933, d. 784 Stenogramma Vsesoiuznoi konferentsii po razmeshcheniiu proizvoditel'nykh sil v UKK [Uralo-Kuznetskii Kombinat], 7-11 aprelia 1932,1. 25.

56. RGAE, f.8034 Glavtsvetmet, op. 1, d. 453 Piatiletnii plan razvitiia tsvetnoi i zolotoplatinovoi promyshlennosti na Urale na 1933-1937 gg., 11. 170-181. The billion ruble figure excluded the costs of geological research and construction in the gold and platinum industries.

57. GAAO SO, f. 1, op. 2 Lichnye dela, d. 22861 Delo Sedasheva, 1. 33.

58. Materials were also faked in the justification of the Sinara pipe factory project. Here too production could not physically meet plan targets because of the lack of ores. Ibid., d. 22329 Delo Davydova, Andreia Aleksandrovicha, 1.5.

59. For a statement of the Urals ambitions for the second five-year-plan, see GASO, f. 241-r Oblplan, op. 1 Sektsiia promyshlennaia, d.827 Perspektivnyi plan UKK (Ural'skoi chasti) na 1931-1937, 11. 33-35. Gosplan criticised the Urals region for pushing "fantastical tempos", RGAE, f. 4372 Gosplan, op. 30 1932, d. 784 Pervaia konferentsiia po razmeshcheniiu proizvoditel'nykh sil v UKK, 1.3 . 
state" 60 contrasted sharply with the free spending of the first five-year plan. But the most serious problem was rooted in the region's first five-year plan. Many of the key projects were dependent on the supplies of coal and ores that, as regional officials knew well, simply did not exist. As new plants were completed and were to account for an ever larger share of production, as ever greater efficiency was demanded of them, the plan became progressively more difficult to fulfil. Urals officials knew they were in trouble, that plan targets could not be fulfilled.

They responded by developing strategies of self-protection. Most important of these was the careful control of Moscow's access to information on the state of the regional economy. Similarly, they cultivated an image of themselves as aggressively active in their loyalty to the central leadership and the "Central Committee line" while at the same time trying to reduce plan responsibilities and simplify tasks. A slush fund was run out of the economic administration of the Oblast' Executive Committee which ensured that key members of the regional leadership would have a substantial income, a large apartment, a government car, a country home and so on. ${ }^{61}$ Their professional reputations were systematically promoted at state and party meetings, in public fora and in the press. According to Kabakov, all key positions in the oblast' were under the control of the clique by 1935.62 This even included the local representative of the NKVD, Reshetov, who was very much in the inner circle of the clique, and a close personal friend of Kabakov. ${ }^{63}$

"What resulted was a "wall" which not even the most determined and brave could break through. In addition to which, the combined authority of the leading oblast' organs under our control had been driven so deeply into the minds of the broad party masses, that it was impossible to expect that anyone would attempt to aggregate and draw conclusions from scattered evidence of wrong-doing and criminal activity [...]. This would mean casting suspicion on all elements of the party, state and economic leadership of the oblast'." 64

This state of affairs in which any attempt to criticise or discredit the leadership was likely to draw an overwhelming counterattack gave the members of the clique the confidence to believe that they were "untouchable." 65

Scapegoating was a key tactic of self-protection, and one in which the local NKVD played a central role. In cases of local scandals or problems of plan

60. RGASPI, f. 17 Tsentral'nyi komitet, op. 2 Plenumy, d. 514 Ob"'edinennyi plenum TsK i TsKK VKP(b), 7-12 ianvaria 1933,1.93.

61. GAAO SO, f. 1, op. 2 Lichnye dela, d. 17368 Delo Kabakova, Ivana Dmitrievicha, 1. 68; d. 22861, Delo Sedasheva, 11. 63-64, 174.

62. Ibid., d. 17368 Delo Kabakova, 11. 50-51.

63. The NKVD shared with members of the clique materials it received which could have proved dangerous to its members. Ibid., d. 22861 Delo Sedasheva, 11. 36-37; d. 17368 Delo Kabakova, 1. 64.

64. Ibid., d. 17368 Delo Kabakova, 1. 64.

65. Kabakov used the term. Ibid., 1. 69. 
fulfilment which caught the attention of Moscow, the regional leadership conveniently found an "enemy of the people," often a former oppositionist or some other vulnerable official to take the blame. The idea of internal enemies of the regime that appears to have excited Stalin's mind was by no means discouraged in the regions. On the contrary, Sverdlovsk oblast' and several other regions developed a reputation for holding large numbers of show trials. In 1936, the Commission for Party Control singled out Sverdlovsk and Saratov oblasti for having "completely baselessly arrested and convicted people and undertaken mass repression for minor problems." 66

For the factory director who was not given the option of explaining to his superiors why and how the plan was unrealistic, it was all too easy to find scapegoats, in the guise of "saboteurs" and "counter-revolutionaries," who could take the fall for underfulfilment: construction engineers for faulty work, warehouse directors for the spoilage of inputs, railroad workers for shortages in supply. Similar tactics were employed throughout the oblast' apparatus up to and including the Obkom bureau. For example, the Sverdlovsk Obkom had showed little enthusiasm for the Stakhanovite movement given that it raised production targets and increased administrative tasks without providing clear local benefits. But when the inaction came to the attention of the Politbiuro, and a purge of Obkom department heads was threatened, the Obkom bureau directed the regional legal organs to find cases of "sabotage and resistance" of Stakhanovism in the factory. In the spring of 1936, within Sverdlovsk oblast' there were 236 trials relating to accusations of wrecking in the Stakhanovite movement. ${ }^{67}$ While the Sverdlovsk leadership claimed to be a "solid, monolithic, reliable pillar of the Stalinist Central Committee," it worked with the local NKVD to deflect the pressures of the plan and of campaign politics.

The centre was not aware of the tactics employed by the regional leaders, but it did know that many of its directives were being resisted. In early 1934, Sergo Ordzhonikidze observed that "when we issue directives, we are uncertain whether they will be implemented." 68 Determined to put an end to such a situation, the central leadership created a new set of control organs to check on the fulfilment of decisions. In his speech announcing the establishment of the Commissions for Party and Soviet Control (Komissiia Partiinogo Kontrolia-KPK, Komissiia Sovetskogo Kontrolia-KSK), Stalin made it clear that these organs would be empowered to remove "any responsible official, including officials of the Central Committee" who refused to promptly implement central directives, or as Stalin put it, to remove "officials with well-known services in the past [...] who think that

66. Tsentral'noe Khranenie Sovremennoi Dokumentatsii (TsKhSD), f. 6 KPK, op. 1 Protokoly, d. 59 Zasedanii biuro, 29 fevralia-3 marta 1936, 11. 184-186.

67. TsKhSD, f. 6 , op. 1, d. 59, 11. 184-186.

68. The quotation is of Sergo Ordzhonikidze from early 1934. RGAE, f. 7297 NKTP, op. 38 Sekretariat, d. 104 Stenogramma vystupleniia t. S. Ordzhonikidze na zakrytom partiinom sobranii sotrudnikov NKTP SSSR ob itogakh raboty XVII s"ezda VKP(b), 1. 1. 
party and Soviet laws were written not for them, but for idiots."69 The tide was turning against the regional clique, though it was not yet entirely clear. The threat to remove top officials followed in the aftermath of the disastrous grain collections campaigns of the previous two years in which many local officials had shown a lack of enthusiasm for central targets in the face of widespread famine. But when the Commissions were created, the worst of the famine was over and industrial production was beginning to surge forward. Moscow was less certain about attacking high officials once things had started to improve.

It was not the control organs that undermined the clique in the end, but rather the regional clique's own tactic of scapegoating. The situation in the region was unstable. As production targets increased, it became more difficult to fulfil the plan and hide problems. Industrial accidents were common. Often, ill-trained workers damaged new and expensive equipment. Incomplete or low quality production was frequently shipped despite prohibitions. 1936 was a particularly difficult year. After three years of tolerating unplanned expenditures within industry, the centre imposed tough cost-cutting measures to deal with inter-enterprise debt. As well, the disastrous 1936 harvest put further strain on the economy. ${ }^{70}$ The increasingly desperate state of plan fulfilment accelerated the propensity to scapegoat. In response to the doubling of the accident rate in the Urals non-ferrous metals industry since 1935, Glavtsvetmet recommended educational measures for workers and engineers, but a local trust director insisted that only show trials would reduce the number of accidents. ${ }^{71}$

Cracks had begun to develop within the leadership group itself. The directors of mining enterprises resented the regional machine-builders for the shortage of mining equipment. Directors of the machine-building trusts were upset that they weren't getting the metals they needed. Similarly, the directors of the metal works were angry at the mining enterprises for not supplying them with enough fuels and ores. Meanwhile, state and party leaders were not happy with the directors. The regional leadership was a tinderbox of tensions to which the centre set a spark in the summer of 1936 with the trial of the Trotsky-Zinoviev bloc. Associated with the trial was a central campaign designed to rout the "last remnants of the TrotskyistZinovievite band." It uncovered far more "enemies" than anyone expected. The campaign provoked a firestorm of denunciations beyond the ability of the regional leadership to control. After the trial of the Trotskyist-Zinovievite bloc, tensions within the factory exploded as various groups accused others of "oppositionist activity" by way of assessing blame for poor economic performance. Workers denounced Stakhanovites; Stakhanovites denounced engineers and technical

69. XVII s'"ezd Vsesouznoi Kommunisticheskoi Partii (bol'shevikov). Stenograficheskii otchet (Moscow, Profizdat, 1934): 34-35.

70. Roberta Manning, "The Soviet economic crisis of 1936-1940 and the Great Purges," Stalinist terror: New perspectives (Cambridge, 1993): 129-33.

71. RGAE, f. 8034 Glavtsvetmet, op. 1, d. 938 Stenogramma soveshchaniia aktiva trestov "Uraltsvetmet" i "Uralmed'ruda" po voprosam okhrany truda i tekhniki bezopasnosti na predpriiatiiakh trestov, 10 oktiabria 1936 g., 1.7. 
specialists. District and factory party committees traded accusations that the other was protecting counter-revolutionaries.

Any hopes Kabakov had had for restraining the progress of mutual denunciations vanished in September, when the regional NKVD representative Reshetov was replaced:

"[After the arrival of the new representative, Dmitriev,] the situation changed radically. The ground under our feet got so hot [sic], that I immediately understood that the unmasking of my colleagues and me was only a matter of time."’2

Kabakov was probably trying to flatter his interrogators, but he did have reason to be worried in September. Reshetov had been his friend and ally. He and others had relied on Reshetov to share information and to protect the clique..$^{73}$ Dmitriev was not likely to do the same. According to K. G. Sedashev, the Eastern Steel Trust chairman, Kabakov was "horribly disturbed" by Reshetov's removal. ${ }^{74}$ Fears about Dmitriev were quickly realised. It proved to be impossible to stop his investigations. By the end of May 1937, the almost entire Obkom leadership had been arrested.

\section{Terror and after}

Had Stalin and the central leadership been aware that many regional party organs had controlled the local OGPU/NKVD? It is hard to say, but at the time they created the KPK and KSK to check on the fulfilment of decisions (1934), they had also started to centralise control over the local NKVD. Since their inception, the local political police had been selected by regional organisations on the approval of the central organs. In connection with the formation of the NKVD in 1934, for the first time the central NKVD was to control appointments to highest ranks in the regions..$^{75}$ If this was an attempt to break regional party control, it was not very successful. In Sverdlovsk oblast', nothing changed. Reshetov remained in his favoured place within the Obkom clique, and the same seems to have applied with the NKVD chiefs in many other regions. ${ }^{76}$

This changed suddenly, in the autumn of 1936. After he took the reins of the NKVD, Ezhov initiated a purge of the regional political police. ${ }^{77}$ In Sverdlovsk

72. GAAO SO, f. 1, op. 2 Lichnye dela, d. 17368 Delo Kabakova, t. 1,1.59.

73. Ibid., d. 22861 Delo Sedasheva, 11. 36-37.

74. Ibid., 1.37.

75. A. I. Kokurin and N. V. Petrov, Lubianka: VChK-OGPU-NKVD-MGB-MVD-KGB, 1917-1960. Spravochnik (Moscow, 1997): 167, 192.

76. J. Arch Getty and Oleg V. Naumov, The road to terror: Stalin and the self-destruction of the Bolsheviks, 1932-1939 (New Haven, 1999): 266.

77. The dimensions and targets of the purge remain something of a mystery. Shortly before his execution, Ezhov claimed to have purged 14,000 but he does not specify who and over what period of time. Ibid.: 562 . 
oblast', Dmitriev's investigations quickly uncovered the great scale of collusion between the regional party and NKVD in the subversion of central directives. It would not be surprising if a very large proportion of regional political police had been purged (and arrested), and it was unlikely indeed that the centre would allow such collusion to re-emerge. In May 1939, a directive of the All-Union NKVD formalised a new administrative order in which all appointments to the local political police were controlled from the centre. Control over the fulfilment of NKVD decisions was to be checked by a new NKVD Secretariat..$^{78}$

On the heels of the arrest and execution of the previous two Obkom first secretaries, the Sverdlovsk regional leadership was desperate to set a distance between itself and its predecessors. When faced with evidence of underfulfilment, the new first secretary V. M. Andrianov told his department heads and enterprise directors to "work twenty-four hours a day" if they had to, "but fulfil the directives of the Central Committee completely and unconditionally" ${ }^{79}$ At the same time, the regional leadership was at pains to explain the shift in tasks from the "struggle against wrecking" to the "struggle against the consequences of wrecking." In their speeches, the "consequences of wrecking" referred to the coping mechanisms of their predecessors. Passing incomplete or faulty production, cutting corners on production safety and other coping mechanisms had facilitated an impression of plan fulfilment while making stable advances in production more difficult. At an Obkom plenum in late 1939, directors and department were told not to look for wreckers, but to take more responsibility for the state of affairs where they worked. The message met with resistance. It was no easier to meet the plan now than it had been in the mid-1930s, and they still needed to cut corners. Accidents, breakdowns and other "suspicious" events were still very common. The spectre of wrecking still presented an invaluable opportunity to pass the blame for problems of production. At party and state meetings, factory directors and local party officials continued to assess accidents and breakdowns as the work of wreckers and saboteurs..$^{80}$

Did they believe in an immanent threat from wreckers? One local assistant plenipotentiary of the NKVD wrote to Beriia asking for clarification. On the one hand, he wrote, his bosses continued baselessly to arrest innocent people. On the other hand, many others "on whom there was weighty compromising material" were being set free..$^{81}$ No clarification was forthcoming. The centre discouraged mass arrests, but it continued to demand vigilance against wreckers, spies and

78. A. I. Kokurin and N. V. Petrov, op. cit.: 235-236.

79. TsDOO SO, f. 4, op. 34 1939, d. 9 Stenogramma XI plenuma Sverdlovskogo oblastnogo komiteta VKP(b), 29 noiabria-2 dekabria 1939 g., 11. 249-250.

80. TsDOO SO, f. 4, op. 33 1938, d. 19 Stenogramma III plenuma Sverdlovskogo oblastnogo komiteta VKP(b), 15-18 dekabria 1938 g., 11. 30, 34; op. 34 1939, d. 151 Stenogrammy soveshchanii rabotnikov apparata obkoma, zaveduiushchikh otdelami, sekretarei gorkomov i raikomov partii po voprosu o perestroike partiinogo apparata, 11. 30-31.

81. TsDOO SO, f. 4, op. 35 1940, d. 300 Dokladnye zapiski, spravki o rabote s kadrami v oblastnoi prokurature, ob itogakh i nedostatkakh $\mathrm{v}$ rabote sudebno-prokuraturskikh organov i rukovoditelei predpriiatii po vypolneniiu ukaza Verkhovnogo Soveta SSSR ot 26 iiulia 1940, 11. 47-51. 
saboteurs. While regional officials were responsible for total plan fulfilment in the absence of any input to the plan, or flexibility in the means by which they met plan targets, they continued to evade central directives and to scapegoat others for shortcomings in production. ${ }^{82}$

Such strategies fooled the centre for some time in the 1930s. They did not fool anyone now - not merely because Moscow was better equipped to detect them, but also because the oblast' level party "clique" did not have the same power to dominate politics in the region. The party was much larger now, with many more positions of independent authority. Officials were better educated and much less inclined to be in awe of the Obkom secretary and his membership on the Central Committee. And the local representative of the NKVD/MGB/MVD could no longer be relied upon to enforce the will of the regional party leaders. In place of a single, dominant, regional "clique," or "family group" to provide patronage and protection, local officials were more likely to be a part of smaller, city, district or factory level "cliques" which managed their self-presentation to the outside world. Loyalties were much less clear. The political police at all levels found it difficult to work without some co-operation with corresponding party organs and some found a certain level of mutual back-scratching advantageous. There was, however, no dominant oblast' level clique to keep a lid on local tensions, and the stronger, "vertical" checks on the fulfilment of decisions made those "horizontal" backscratching relationships terribly unreliable.

All this made regional politics more tense and conflictual than they had been in the 1930s. When production problems deepened to the point where masking problems was impossible, there was no group that could prevent or control the process of scapegoating. For example, when the Uralmash plant was unable to hide serious plan underfulfilment in 1949, the Industry and Transport Department of the Sverdlovsk City Committee together with the local representatives of the MGB revealed the "anti-state practice of plan falsification" (pripiski $k$ planu) at the factory ${ }^{83}$ In that way, they would not have to answer for the mess. Similarly, when the regional coal industry was criticised from Moscow, the oblast' leadership accused the party secretaries of the coal producing districts of suppressing local criticism and hiding production problems from them..$^{84}$

82. Local party leaders and enterprise directors continued to lie about the state of plan fulfilment. Reports on plan fulfilment almost invariably were set in ruble terms, which hid creative adjustments to the nomenclature of production and took advantage of inflation. Demands for inputs were exaggerated, and unused plant capacities went unmentioned. Overfulfilment in any given month was unreported and applied against subsequent shortfalls See Joseph Berliner, Factory and manager in the USSR (Cambridge, Mass., 1957).

83. TsDOO SO, f. 4, op. 45 1949, d. 196 Dokladnye zapiski, spravki partiinykh rabotnikov, rukovoditelei khoziaistvennykh organisatsii $\mathrm{v}$ obkom partii o sostoianii i rabote predpriiatii tiazheloi i mashinostroitel'noi promyshlennosti oblasti, ianvar'-sentiabr' 1949 g., 11. 47-56

84. TsDOO SO, f. 4, op. 45 1949, d. 211 Spravki, informatsii rabotnikov obkoma, gorkomov, raikomov $\mathrm{VKP}(\mathrm{b}) \mathrm{v}$ obkom partii o rasmotrenii zhalob i zaiavlenii na nepravil'nye deistviia rukovoditelei, zazhime kritiki, aprel'-oktiabr' 1949, 1l. 26-29, 43-45. 
The regular conflicts between the Obkom, on the one hand, and the district and city party committees, on the other, were particularly severe and consequential. In his tenure as Obkom first secretary (1946-1952), Viktor Nedosekin never managed to create the impression of plan fulfilment. While his reports to Moscow spoke of the great advances of Urals industry, there were other sources of information painting a far less flattering picture. ${ }^{85}$ In 1948, Nedosekin was hauled into the Orgbiuro and told that if he failed to turn things around he would be removed ${ }^{86} \mathrm{In}$ turn, he tried to lay the blame for problems on the district and city party committees and had them removed en masse. The annual rate of turnover of district and city party secretaries often exceeded 50\%.87 Like Andrianov before him, he had a reputation for destroying the careers of those who crossed him. ${ }^{88}$ And yet, Nedosekin succeeded only in building the ire of the local secretaries, who in turn relentlessly criticised the Obkom before central officials for failing to give them appropriate assistance. In the summer of 1951, the Central Committee apparatus began to transfer Obkom secretaries out of the oblast'. By September all mention of Nedosekin disappears from the local archives, though his replacement was named only in September of 1952.

On the eve of Stalin's death, there were signs that scapegoating might lead to a new wave of terror against the regions. Many of the sorts of corruption and abuses of power revealed in the Mingrelian affair were common to all the regions. ${ }^{89}$ Certainly, Moscow was losing patience with regional organisations for misleading them about plan fulfilment and relying on "family groups" to protect their local authority..$^{90}$ The new party statutes passed at the XIX Party Congress made it clear that "hiding and perverting the truth from the party [...] was incompatible with membership in its ranks" as was anything less than the "active struggle for the fulfilment of party decisions." 91 More seriously, a decree of the Council of Ministers earlier in the year had increased the punishment for some categories of

85. The sources include district and city party committees, regional plenipotentiaries and the ministries. RGASPI, f. 17, op. 134 Otdel tiazheloi promyshlennosti TsK VKP(b), d. 8 Proekty postanovlenii Sovmina SSSR, podgotovlennye Sverdlovskim obkomom VKP(b), spravki po nim Otdela, zakliucheniia ministerstv i vedomstv, oktiabr' 1948-ianvar' 1949 g., 11. 55-58.

86. TsDOO SO, f. 4, op. 44 1948, d. 14 Stenogramma zasedaniia IV plenuma Sverdlovskogo obkoma VKP(b), 29-30 noiabria 1948 g., 11. 120-132 doklad tov. Prassa (inspektor TSK).

87. TsDOO SO, f. 4, op. 52 1954, d. 180 Statisticheskie otchety, spravki o podbore, podgotovke, rasstanovke i smeniaemosti rukovodiashchikh partiinykh, sovetskikh, komsomol'skikh i khoziaistvennykh kadrov oblasti, ianvar' 1950-ianvar' 1954 g., 1. 64 Dannye o smeniaemosti sekretarei partorg i ikh zamestitelei po GK i RK.

88. TsDOO SO, f. 4, op. 55 1956, d. 105 Informatsii Obkoma v TsK KPSS o provedenii organizatsionno-partiinoi raboty v oblasti, 1. 168 .

89. Ultimately, however, "nationalism" was the most serious of the charges laid against Georgian party leaders.

90. See for example Khrushchev's speech to the XIX Party Congress in October 1952, RGASPI, f. 592 XIX s',ezd VKP(b) 5-14 oktiabria 1952 g., op. 1, d. 44 Stenogramma desiatogo zasedaniia 10-go oktiabria. Doklad sekretaria TSk Khrushcheva, N. S., ob izmeneniiakh v ustave VKP(b), 11. 16-19.

91. KPSS v rezoliutsiiakh..., op. cit., v. 8: 286. 
plan falsification, equating them with wrecking. ${ }^{92}$ Prosecutions did follow - on charges of counter-revolutionary crimes, ${ }^{93}$ but the signals from Moscow were not strong enough or consistent enough to incite a broader wave of denunciations as there had been in 1936-1938.

For nearly two decades, the regional organs of the political police were officially subordinated dually: to their central counterparts and to the regional party committee. Initially, dual subordination involved few contradictions. The local "organs" served both masters, both in the destruction of "oppositions" and in the promotion of ambitious economic plans. However, in the early 1930s, under the extraordinary demands of the five-year plans, many regional party leaders demonstrated that they had the stronger grip on the loyalties of the local political police. The local "organs" played a crucial role in the protection of regional cliques from the pressures of plan fulfilment. They would find and arrest "wreckers" and "saboteurs": those who would take the blame for production problems. The blame shifting strategy collapsed in 1936 and contributed to the Great Terror. After that, the centre took care to prevent the regional party and political police to collude in the subversion of central directives. After 1939, the centre chose all local political police agents, and carefully monitored their activities. The results of the change were mixed at best. Not all collusion was eliminated, though the centre was much better informed about bureaucratic malfeasance. The information came not from a disciplined local political police, but from an almost uncontrolled tendency to scapegoat at all levels. The close relationship of the regional party and political police had done much to stabilise the local political order in the Soviet Union. And that stability was not restored until after Stalin's death, when Khrushchev eased the pressures of plan fulfilment, restricted the powers of the political police and tolerated all but the most egregious forms of regional misbehaviour.

\author{
School of History \\ University of Leeds \\ Leeds LS2 9JT \\ $U K$
}

j.r.harris@leeds.ac.uk

92. TsDOO SO, f. 4, op. 52 1953, d. 112 Stenogramma soveshcvhaniia rabotnikov promyshlennosti, stroitel'nykh organizatsii i transporta Sverdlovskoi oblasti, 28-29 ianvaria 1953 g., 1. 181.

93. Ibid., 1. 178; TsDOO SO, f. 4, op. 52 1953, d. 10 Stenogramma ob'”edinennogo plenuma oblastnoi i gorodskoi komitetov KPSS, 13 iiunia 1953 g., 11. 74-78. 